Ekonomis: Journal of Economics and Business, 5(1), Maret 2021, 46-52

Publisher: Lembaga Penelitian dan Pengabdian kepada Masyarakat Universitas Batanghari Jambi Address: Jl. Slamet Ryadi, Broni-Jambi Kodepos: 36122

Website: http://ekonomis.unbari.ac.id, email: ekonomis.unbari@gmail.com ISSN 2597-8829 (Online), DOI 10.33087/ekonomis.v5i1.200

\title{
Pengaruh Good Corporate Governance, Modal Intelektual, Ukuran Perusahaan terhadap Kinerja Keuangan pada Perusahaan Makanan
}

\author{
Arief Abdul Aziz ${ }^{*}$, Yuli Chomsatu Samrotun, Riana Rachmawati Dewi \\ Universitas Islam Batik Surakarta \\ *Correspondence email: ariefabdul1234@gmail.com, you.liechoms@gmail.com, rianardewi1@gmail.com
}

\begin{abstract}
Abstrak. Tujuan penelitian ini adalah untuk menguji pengaruh good corporate governance, modal intelektual, dan ukuran perusahaan terhadap kinerja keuangan (ROA) perusahaan makanan dan minuman. Sampel penelitian ini adalah perusahaan makanan dan minuman yang terdaftar di Bursa Efek Indonesia (BEI). Analisis yang digunakan dalam penelitian ini adalah analisis regresi linier berganda. Hasil penelitian menunjukkan bahwa good corporate governance terdiri dari beberapa indikator, indikator tersebut menunjukkan bahwa ukuran dewan komisaris berpengaruh terhadap kinerja keuangan (ROA), komisaris independen tidak berpengaruh terhadap kinerja keuangan (ROA), dan komite audit independen berpengaruh terhadap kinerja keuangan (ROA) dan kepemilikan institusional. Tidak ada pengaruh terhadap kinerja keuangan (ROA), kepemilikan manajer tidak berpengaruh terhadap kinerja keuangan (ROA), dan ukuran komite juga berpengaruh terhadap kinerja keuangan (ROA). Selain indikator tata kelola perusahaan yang baik, modal intelektual tidak berpengaruh terhadap kinerja keuangan (ROA), dan ukuran perusahaan juga berpengaruh terhadap kinerja keuangan.
\end{abstract}

Kata kunci: Good Corporate Governance; Modal Intelektual; Ukuran Perusahaan.

Abstrack. The purpose of the study is to test the impact of good corporate governance, intellectual capital, and corporate size on food and beverage performance. This study sample is a food and beverage company registered in the Indonesian stock exchange. The analysis used in this study is linked to linear regression analysis. Studies show that good corporate governance consists of a few indicators, these indictments show that the size of the board of commissioners affects financial performance (roa), independent commissioners have no effect on financial performance (roa), and independent auditing committees affect financial performance (roa) and institutional ownership. No influence on financial performance (roa), the manager's ownership has no effect on financial performance (roa), and the committee's size also affects financial performance (roa). Apart from good company governance indicators, intellectual capital has no effect on financial performance (roa), and the company's size also affects financial performance.

Keywords: good corporate governance; intellectual capital; corporate size.

\section{Pendahuluan}

Tujuan dari penelitian ini adalah untuk mengetahui pengaruh good corporate governance, modal intelektual, ukuran perusahaan terhadap kinerja keuangan perusahaan makanan. Dalam penelitian ini, tata kelola perusahaan yang baik meliputi ukuran dewan direksi, komisaris indepen, komite audit indepen, kepemilikan institusi, kepemilikan manajerial, dan ukuran dewan komisaris. Data keuangan periode pertama 2020 PT Kino mampu menghasilkan keuntungan yang ternyata mengalami penurunan pada kuartal pertama dari sebelumnya sebesar $67,52 \%$, terjadi juga pada PT Garudafood Putra Putri Jaya Tbk (GOOD) yang menyatakan mengalami penurunan sebesar 1,75\%, data tersebut didapat dari data keuangan perusahaan atau dari rasio keuangan yang ada.

Kinerja keuangan merupakan tolak ukur untuk mengukur apakah kinerja suatu perusahaan baik atau tidak, terlihat dari laporan keuangan bahwa kinerja keuangan dapat diukur dari dua aspek yaitu internal dengan melihat laporan keuangan perusahaan dan / atau melalui eksternal yaitu nilai perusahaan dengan menghitung kinerja keuangan perusahaan. Penelitian ini merupakan pengembangan dari beberapa hasil penelitian tentang Good Corporate Governance, modal intelektual dan ukuran perusahaan terhadap kinerja keuangan. Perbedaan antara penelitian ini dengan penelitian sebelumnya terletak pada jumlah variabel yang merupakan periode tahun penelitian. Objek penelitian ini adalah perusahaan manufaktur industri barang konsumsi yang terdaftar di BEI selama tahun 2017-2019.

\section{METODE}

Penelitian ini menggunkan penelitian kuantitatif dan menggunakan data perusahaan manufaktur yang terdaftar di BEI pada tahun 2017-2019. Data yang digunkan yaitu menggunakan data sekunder, berupa laporan tahunan perusahaan makanan minuman yang terdaftar di BEI. Data didapat dari situs www.idx.co.id dari masing-masing perusahaan.

Variabel dependen yang digunakan dalam penelitian ini menggunakan ROA. 
ROA $=\frac{\text { Laba Bersih }}{\text { Total Aset }}$

Variabel independen dalam penelitian ini yaitu terdiri dari

1. Ukuran Dewan Direksi Ukuran dewan komisaris $=\sum$ Anggota dewan direksi

2. Komisaris Independen

$\mathrm{DKI}=\frac{\sum D K I}{A D K}$

3. Komite Audit Independen

$\mathrm{KA}=\sum$ Anggota Komite Audit

4. Kepemilikan Instituti

$K I=\frac{\sum S I}{\sum S B}$

5. Kepemilikan Manajerial

$K M=\frac{\sum S M}{\sum S B}$

6. Ukuran Dewan Komisaris $U D K=\sum$ Dewan Komisris

7. Ukuran Perusahaan $S I Z E=\log ($ Total Aset $)$

8. Modal Intelektual

$V A=O U T-I N$

$S C=V A-H C$

a. $V A C A=\frac{V A}{C E}$

b. $\quad V A H U=\frac{V A}{H C}$

c. $S T V A=\frac{S C}{V A}$

d. $V A I C T M=V A C A+V A H U+S T V A$

\section{Uji Asumsi Klasik}

1. Uji Normalitas, uji normalitas yaitu berfungsi untuk menguji normal atau tidaknya model regresi variabel RES.

2. Uji Multikolinearitas, uji multikolinearitas yaitu berfungsi utuk menguji terdapat atau tidaknya korelasi antar variabel bebas.

3. Uji Hekteroskedastisitas, uji heteroskedastisitas bertujuan untuk mencari perbedaan varian residual antara pengamatan satu dan lainnya.

4. Uji Autokorelasi, uji autokorelasi untuk menguji korelasi variabel yang terdapat pada model regresi.

\section{Uji Regresi Linier Berganda}

1. Model Regresi

Model regresi linier berganda dilakukan pada model yang diajukan menggunakan software SPSS untuk mengukur seberapa besar pengaruh variabel independen terhadap variabel dependen (Ghozali, 2016).

$\mathrm{Y}=\mathrm{a}+\mathrm{b} 1 . \mathrm{X} 1.1+\mathrm{b} 2 . \mathrm{X} 1.2+\mathrm{b} 3 . \mathrm{X} 1.3+\mathrm{b} 4 . \mathrm{X} 1.4+\mathrm{b} 5 . \mathrm{X} 1.5+\mathrm{b} 6 . \mathrm{X} 1.6+\mathrm{b} 7 . \mathrm{X} 2+\mathrm{b} 8 . \mathrm{X} 3+\mathrm{e}$

Keterangan: Y : Kinerja Keuangan; a : Konstanta; b : Koefisien Regresi; X1.1 : Ukuran Dewan Direksi X1.2 : Komisaris Independen; X1.3 : Komite Audit Independen; X1.4 : kepemilikan Instituti; X1.5 : Kepemilikan Manajerial; X1.6 : Ukuran Dewan Komisaris; X2 : Ukuran Perusahaan; X3 : Modal Intelektual; e : error

2. Uji Kelayakan Model (Uji F)

Secara mendasar apakah veriabel independen berpengaruh secara simultan terhadap variabel dependen. Cara melakukan Uji F adalah dengan melihat acuan signifikasi, yaitu 0,05.

3. Uji Hipotesis (Uji t)

Uji signifikasi parameter individual (uji t) untuk membuktian apakah secara parsial variabel independen dapat berpengaruh signifikan terhadap variabel dependen.

4. Uji Koefisien Determinasi $\left(\mathrm{R}^{2}\right)$

Inti dari uji koefisien determinasi (Adjusted $R$-Square) adalah untuk menguji sejauh mana model regresi dapat menjelaskan variasi variabel dependen. Nilai dari koefisien determinasi (Adjusted R-Square) adalah antara 0 dan 1. 
Arief Abdul Aziz, Yuli Chomsatu Samrotun dan Riana Rachmawati Dewi, Pengaruh Good Corporate Governance, Modal Intelektual, Ukuran Perusahaan Terhadap Kinerja Keuangan Pada Perusahaan Makanan

Penelitian ini menggunakan purposive sampling atau kriteria-kriteria yang telah ditentukan untuk mendapatkan sampel yang sesuai dengan tujuan. Jumlah data yang digunakan pada perusahaan makanan minuman pada tahun $2017-$ 2019 yang telah lulus kriteria sebanyak 36 data dan 16 perusahaan.

HASIL DAN PEMBAHASAN

Tabel 1.

One Sample Kolmologorov Smirnov

\begin{tabular}{ccccr}
\hline Variabel & Sign & Probabilitas & Kesimpulan \\
\hline Asymp.Sig (2-tailed) & & 0,785 & 0,05 & Data Normal \\
\hline
\end{tabular}

Sumber: olahan data

Tabel 2.

Hasil Uji Multikolinieritas

\begin{tabular}{lrrrrl}
\hline \multicolumn{1}{c}{ Variabel } & Tolerance & Std & VIP & Std & Keterangan \\
\hline Ukuran Dewan Direksi & 0,277 & 0,10 & 4,410 & 10 & Tidak terjadi Multikolinieritas \\
Komisaris Independen & 0,593 & 0,10 & 1,687 & 10 & Tidak terjadi Multikolinieritas \\
Komite Audit Independen & 0,520 & 0,10 & 1,921 & 10 & Tidak terjadi Multikolinieritas \\
Kepemilikan Instituti & 0,555 & 0,10 & 1,801 & 10 & Tidak terjadi Multikolinieritas \\
Kepemilikan Manajerial & 0,617 & 0,10 & 1,622 & 10 & Tidak terjadi Multikolinieritas \\
Ukuran Dewan Komisaris & 0,237 & 0,10 & 4,216 & 10 & Tidak terjadi Multikolinieritas \\
Ukuran Perusahaan & 0,304 & 0,10 & 3,284 & 10 & Tidak terjadi Multikolinieritas \\
Modal Intelektual & 0,588 & 0,10 & 1,701 & 10 & Tidak terjadi Multikolinieritas \\
\hline
\end{tabular}

Sumber: olahan data

Tabel 3.

Hasil Uji Hekteroskedastisitas

\begin{tabular}{lrrr}
\hline \multicolumn{1}{c}{ Variabel } & Sign & Standart & kesimpulan \\
\hline Ukuran Dewan Direksi & 0,864 & 0,05 & Tidak terjadi hekterokedastisitas \\
Komisaris Independen & 0,716 & 0,05 & Tidak terjadi hekterokedastisitas \\
Komite Audit Independen & 0,685 & 0,05 & Tidak terjadi hekterokedastisitas \\
Kepemilikan Instituti & 0,787 & 0,05 & Tidak terjadi hekterokedastisitas \\
Kepemilikan Manajerial & 0,443 & 0,05 & Tidak terjadi hekterokedastisitas \\
Ukuran Dewan Komisaris & 0,462 & 0,05 & Tidak terjadi hekterokedastisitas \\
Ukuran Perusahaan & 0,428 & 0,05 & Tidak terjadi hekterokedastisitas \\
Modal Intelektual & 0,560 & 0,05 & Tidak terjadi hekterokedastisitas \\
\hline
\end{tabular}

Sumber: olahan data

Tabel 3.

Hasil Uji Autokorelasi

Asymp. Sig ketentuan

$0,063 \quad>0,05$

Sumber: olahan data

Pengujian penelitian ini terdiri dari uji Kolmogrof-smirnov test untuk menguji normalitas data secara statistik. uji multikolinieritas dengan menggunakan dua varian yaitu satu Variance Inflation Facos (VIP) dua tolerance, uji heteroskedastisitas dengan menggunakan metode Ustandardised Residual, uji autokorelasi dengan menggunakan RUN TEST. Data yang diolah normal, tidak terjadi multikolinieritas atar variabel independen, tidak terdapat adanya hekteroskedastisitas dan tidak terdapat gejala autokorelasi.

Tabel 4.

Hasil Uji Regresi

\begin{tabular}{lr|r}
\hline & Model & Unstandardized Coefficients (B) \\
\hline (Constant) & & 0,863 \\
Ukuran Dewan Direksi & $-0,024$ \\
Komisaris Independen & $-0,365$ \\
Komite Audit Independen & 0,067 \\
Kepemilikan Instituti & 0,009 \\
Kepemilikan Manajerial & $-0,126$ \\
Ukuran Dewan Komisaris & 0,063 \\
Ukuran Perusahaan & $-0,077$ \\
Modal Intelektual & 0,001 \\
\hline
\end{tabular}

Sumber: olahan data 
a. Nilai constant sebesar 0,863, maka dapat diartikan jika variabel ukuran dewan direksi, komisaris independen, komite audit independen, kepemilikan instituti, kepemilikan manajerial, ukuran dewan komisaris, ukuran perusahaan, modal intelektual diasumsikan dengan nilai 0 (kostan), maka kinerja keuangan (ROA) akan bertambah sebesar 0,863 .

b. Niali koefisien variabel ukuran dewan direksi sebesar -0,024, maka dapat diartikan bahwa satiap kenaikan satuan ukuran dewan direksi maka menurunkan kinerja keuangan (ROA) sebesar 0,024.

c. Nilai koefisien variabel komisaris independen sebesar -0,365, maka dapat diartikan bahwa setiap kenaikan satuan komisaris independen maka menurunkan kinerja keuangan (ROA) sebesar 0,365.

d. Nilai koefisien variabel komite audit independen sebesar 0,067, maka dapat diartikan bahwa setiap keniakan satuan komite audit independen maka juga akan dapat menaikan kinerja keuangan (ROA) sebesar 0,067.

e. Nilai koefisien variabel kepemilikan instituti sebesar 0,009, maka dapat diartikan bahwa setiap kenaikan satuan kepemilikan instituti makan menurunan kinerja keuangan (ROA) sebesar 0,009.

f. Niali koefisien variabel kepemilikan manajerial sebesar -0,126, maka dapat diartikan bahwa setiap kenaikan satuan kepemilikan manajerial maka menurunkan kinerja keuagan (ROA) sebesar 0,126.

g. Nilai koefisien variabel ukuran dewan komisaris sebesar -0,063, maka dapat diartikan bahwa setiap kenaikan sautan ukuran dewan komisaris maka menurunkan kinerja keuangan (ROA) sebesar 0,063.

h. Nilai koefisien variabel ukuran pesusahaan sebesar -0,077, maka dapat diartikan bahwa setiap kenaikan satuan ukuran perusahaan maka menunurunkan kinerja keuangan (ROA) sebesar 0,077.

i. Nilai koefisien variabel modal intelektual sebesar 0,001 , maka dapat diartikan bahwa setiap kenaikan modal intelektual maka menaikan kinerja keuangan (ROA) sebesar 0,001

Tabel 5.

Hasil Uji F

\begin{tabular}{llllll}
\hline Keterangan & F $_{\text {hitung }}$ & F $_{\text {tabel }}$ & Sig & Kriteria & Hasil \\
\hline Uji Kelayakan Model & 3,763 & 2,37 & 0,004 & $<0,05$ & Model Layak \\
\hline
\end{tabular}

Sumber: olahan data

Tabel 5 diatas dapat di lihat nilai $\mathrm{F}_{\text {hitung }}$ 3,763 didapat dari hasil uji spss sedangkan nilai $\mathrm{F}_{\text {tabel }}$ 2,37 didapat dari df1 (jumlah variabel-1) $=8-1=7$ dan df2 $(n-k-1)=36-8-1=27$. Dari hasil uji menunjukan bawa $F_{\text {hitung }}>F_{\text {tabel }}$ $(3,763>2,37)$ dan nilai sig $(0,004<0,05)$, sehingga dapat disimbulkan bahwa nilai variabel Dewan Direksi, Komisaris Independen, Komite Audit Independen, Kepemilikan Instituti, Kepemilikan Manajerial, Ukuran Dewan Komisaris, Ukuran Perusahaan, Modal Intelektual secara simulta berpengaruh terhadap kinerja keuangan (ROA).

Tabel 6.

Hasil Uji Hipotesis (Uji t)

\begin{tabular}{|c|c|c|c|c|c|}
\hline Hipotesis & thitung $_{\text {his }}$ & $\mathbf{t}_{\text {tabel }}$ & Sig. & Kreteria & Kesimpulan \\
\hline Ukuran Dewan Direksi (H1.1) & $-2,290$ & $<-2,052$ & 0,030 & $<0,05$ & Diterima \\
\hline Komisaris Independen (H1.2) & $-1,834$ & $<-2,052$ & 0,078 & $<0,05$ & Ditolak \\
\hline Komite Audit Independen (H1.3) & 2,166 & $>2,052$ & 0,039 & $<0,05$ & Diterima \\
\hline Kepemilikan Instituti(H1.4) & 0,255 & $>2,052$ & 0,801 & $<0,05$ & Ditolak \\
\hline Kepemilikan Manajerial(H1.5) & $-1,065$ & $<-2,052$ & 0,296 & $<0,05$ & Ditolak \\
\hline Ukuran Dewan Komisaris (H1.6) & 4,985 & $>2,052$ & 0,000 & $<0,05$ & Diterima \\
\hline Ukuran Perusahaan (H2) & $-3,349$ & $<-2,052$ & 0,002 & $<0,05$ & Diterima \\
\hline Modal Intelektual (H3) & 1,137 & $>2,052$ & 0,266 & $<0,05$ & Ditolak \\
\hline
\end{tabular}

Sumber: olahan data

Nilai t tabel diperoleh dari pengujian menggunakan tingkat signifikansi 0,05 dan 2 sisi, sehingga $0,05 / 2=0,025$ dengan drajat kebesaran $\mathrm{df}=\mathrm{n}-\mathrm{k}-1=51$. Perolehan $\mathrm{t}$ tabel sebesar 2,05183.

Tabel 7.

Hasil Uji Determinasi

\begin{tabular}{lll}
\hline Model & Adjusted R Square & Keterangan \\
\hline 1 & 0,387 & Pengaruh keseluruhan variabel independen terhadap variabel dependen sebesar $38,7 \%$ \\
\hline
\end{tabular}

Sumber: olahan data

Berdasarkan hasil uji determinasi nilai Adjusted R Square sebesar 0,387. Besar pengaruh variabel independen terhadap variabel dependen sebesar $38,7 \%$. Sisanya yaitu $100 \%-38,7 \%=61,3 \%$ dijelaskan oleh variabel-variabel diluar yang berada diluar penelitian. 
1. Pengaruh ukuran dewan direksi terhadap kinerja keuangan (ROA).

Hasil penelitian menunjukan ukuran dewan direksi berpengaruh terhadap kinerja keuangan (ROA). Dilihat dari tabel $\mathrm{t}$ hitung $-2,290<2,05183 \mathrm{t}$ tabel dengan nilai signifikansi sebesar $0,030<0,05$ maka Ho ditolak dan $\mathrm{H}_{1.1}$ diterima. Sehingga hipotesis 1 berpengaruh terhadap kinerja keuangan.

Besar atau kecilnya ukuran dewan direksi berpengaruh terhadap kinerja keuangan. Ukuran dewan direksi bertugas untuk menentukan arah kebijakan dan strategi sumber daya yang dimiliki oleh perusahaan, baik untuk jangka panjang maupun jangka pendek, sehingga ukuran dewan direksi berpengaruh efektif dalam menjalankakan tugasnya untuk menentukan arah kebijakan dan strategi sumber daya yang dimiliki perusahaan. Penelitian ini sejalan dengan penelitian Diyanty \& Yusniar (2019) dan Alina \& Anis (2014) yang menyatakan bahwa ukuran dewa direksi berpengaruh terhadap kinerja keuangan. Akan tetapi penelitian ini tidak sejalan dengan penelitian Wehdawati, Fifi, \& Sufi (2015) yang menyatakan bahwa ukuran dewan direksi tidak berpengaruh terhadap kinerja keuangan.

2. Pengaruh komisaris independen terhadap kinerja keuangan (ROA).

Hasil penelitian menunjukan komisaris independen tidak berpengaruh terhadap kinerja keuangan (ROA). Dilihat dari $\mathrm{t}$ hitung sebesar $-1,834<2,05183 \mathrm{t}$ tabel dengan nilai signifikansi sebesar 0,078 $>0,05$ maka Ho diterima dan $\mathrm{H}_{1.2}$ ditolak. Sehingga hipotesis 2 komisaris independen tidak berpengaruh terhadap kinerja keuangan.

Jumlah komisaris independen tidak berpengaruh terhadap kinerja keuangan. Sehingga ini bertolak belekang dengan pedoman Good Corporate Governance yang menyatakan bahwa komisaris independen harus menjamin pengawasan secara efektif. Komisaris independen bertugas untuk melakukan pengawasan dan nasehat kepada para direktur, komisaris independen hanya untuk pemenuhan regulasi sehingga dewan komisaris independen tidak efektif dalam menjalankan tugasnya besar kecilnya ukuran dewan komisaris independen hanya sebagai formalitas untuk pemenuhan dalam menjalankan Good Corporate Governance. Selain itu pengawasan dewan komisaris independen belum bisa menyelesaikan agency problem didalam perusahaan. Hal ini yang dapat mengakibatkan dewan komisaris independen dianggap sebagai simbol (Tandean \& Winnie, 2016). Penelitian ini sejalan dengan penelitian Hendrian \& Fajri (2020) yang menyatakan bahwa komisaris independen tidak berpengaruh terhadap kinerja keuangan. Akan tetapi penelittian ini tidak sejalan dengan Okta \& Iwan (2020) yang menyatakan bahwa komisaris independen berpengaruh terhadap kinerja keuangan.

3. Pengaruh komite audit independen terhadap kinerja keuangan (ROA).

Hasil penelitian menunjukan komite audit berpengaruh terhadap kinerja keuangan. Dilihat dari t hitung sebesar 2,166 $>2,05183$ t tabel dengan nilai signifikansi sebesar $0,039<0,05$ maka Ho ditolak dan $\mathrm{H}_{1.3}$ diterima. Sehingga hipotesis 3 komite audit berpengaruh terhadap kinerja keuangan.

Jumlah komita audit berpengaruh terhadap kinerja keuangan. Komite audit bertugas untuk bertanggung jawab kepada dewan komisaris dalam membantu melaksanakan tugas dan fungsi dewan komisaris. Seperti yang ditetapkan oleh BEI yang menyatakan paling sedikit komite audit berjumlah 3 orang. Sehingga komite audit independen berpengaruh terhadap kinerja keuangan dalam membantu melaksanakan tugas dan fungsi dewan komisars secara netral. Penelitian ini sejalan dengan Okta \& Iwan (2020) yang menyatakan bahwa komite audit independen berpengaruh terhadap kinerja keuangan. Akan tetapi penelitian ini tidak sejalan dengan Diyanty \& Yusniar (2019) yang menyatakan bahwa komite audit independen tidak berpengaruh terhadap kinerja keuangan.

4. Pengaruh kepemilikan instituti terhadap kinerja keuangan (ROA).

Hasil penelitian menunjukkan kepemilikan institusi tidak berpengaruh terhadap kinerja keuangan. Dilihat dari t hitung sebesar $0,255<2,05183 \mathrm{t}$ tabel dengan nilai signifikansi sebesar 0,801 > 0,05 maka Ho diterima dan $\mathrm{H}_{1.4}$ ditolak. Sehingga hipotesis 4 kepemilikan instituti tidak berpengaruh terhadap kinerja keuangan.

Jumlah kepemilikan instituti tidak berpengaruh terhadap kinerja keuangan. Kepemilikan institusional yaitu kepemilikan saham oleh pihak yang berbentuk institusi seperti yayasan, perusahaan investasi, perusahaan berbentuk perseroan (PT) dan institusi lainnya. Jika kepemilikan institusional mendominasi maka mendapatkan respon negatif oleh pasar karena cenderung membuat keputusan yang akan menguntungkan investor institusional dan mengabaikan investor lainnya. Jumlah kepemilikan saham oleh institusi tidak dapat mempengaruhi kinerja keuangan. Jika kepemilikan institusional semakin banyak dapat menimbulkan salah faham, masalah keagenan dan terjadi perseteruan. Penelitian ini sejalan dengan Wehdawati, Fifi, \& Sufi (2015) yang menyatakan bahwa kepemilikan instituti tidak berpengaruh terhadap kinerja keuangan. Akan tetapi penelitian ini tidak sejala dengan Okta \& Iwan (2020) yang menyatakan bahwa kepemilikan instituti berpengaruh terhadap kinerja keuangan.

5. Pengaruh kepemilikan manajerial terhadap kinerja keuengan (ROA).

Hasil penelitian menunjukkan kepemilikan manajerial tidak berpengaruh terhadap kinerja keuangan. Dilihat dari t hitung sebesar $-1,065<2,05183 \mathrm{t}$ tabel dengan nilai signifikansi sebesar 0,296 $>0,05$ maka Ho diterima dan H1.5 ditolak. Sehingga hipotesis kelima kepemilikan manajerial tidak berpengaruh terhadap kinerja keuangan. 
Jumlah kepemilikan manajerial tidak berpengaruh terhadap kinerja keuangan. Kepemilikan manajerial adalah pemegang saham dari pihak manajemen yang secara aktif ikut dalam pengambilan keputusan perusahaan. Dalam pengambilan keputusan kepemilikan manajerial belum mampu menyelaraskan kepentingan pemegang saham diluar manajemen. Semakin besar atau semakin kecil kepemilikan manajerial tetap tidak bisa mengurangi konflik keagenan dalam perusahaan (Wehdawati, Fifi, \& Sufi, 2015). Penelitian ini sejalan dengan Wehdawati, Fifi, \& Sufi (2015) yang menyatakan bahwa kepemilikan manajerial tidak berpengaruh terhadap kinerja keuangan. Akan tetapi penelitian ini tidak sejalan dengan Okta \& Iwan (2020) yang menyatakan bahwa kepemilikan manajerial berpengaruh terhadap kinerja keuangan.

6. Pengaruh ukuran dewan komisaris terhadap kinerja keuangan (ROA).

Hasil penelitian menunjukan ukuran dewan komisaris berpengaruh terhadap kinerja keuangan. Dilihat dari t hitung sebesar 4,985 $>2,05183 \mathrm{t}$ tabel dengan nilai signifikansi $0,000<0,05$ maka Ho ditolak dan $\mathrm{H}_{1.6}$ diterima. Sehingga hipotesis 6 ukuran dewan komisaris berpengaruh terhadap kinerja keuangan.

Ukuran dewan komisaris berpengaruh terhadap kinerja keuangan. Ukuran dewan komisaris bertugas untuk mengawasi dan memberikan nasehat kepada direktur, menurut Beasly (1996) menyatakan bahwa dewan komisaris yang berukuran kecil akan lebih efektif dalam melakukan fungsi pengawasan dibandingkan dewankomisaris yang berukuran besar. Dikarnakan jika semalin besar ukuran dewan komisaris maka akan menimbulkan kesulitan dalam berkomunikasi dan berkoordinasi dalam pengambilan keputusan serta kurang efektifan dalam menjalankan fungsi pengawasan. Penelitian ini sejalan dengan Alina \& Anis (2014) yang menyatakan bahwa ujuran dewan komisaris berpengaruh terhadap kinerja keuangan. Akan tetapi penelitian ini tidak sejalan dengan Diyanty \& Yusniar (2019), Wehdawati, Fifi, \& Sufi (2015) yang menyatakan bahwa ukuran dewan komisaris tidak berpengaruh terhadap kinerja keuangan.

7. Pengarh ukuran perusahaan terhadap kinerja keuangan (ROA).

Hasil penelitian menunjukan bahwa ukuran perusahaan berpengaruh terhadap kinerja keuangan. Dilihat dari $\mathrm{t}$ hitung sebesar $-3,349<2,05183 \mathrm{t}$ tabel dengan nilai signifikansi sebesar 0,002 $<0,005$ maka Ho ditolak dan $\mathrm{H}_{2}$ diterima. Sehingga hipotesis 7 ukuran perusahaan berpengaruh terhadap kinerja keuangan.

Ukuran perusahaan berpengaruh terhadap kinerja keuangan. Hal ini mungkin terjadi karena perusahaan dengan asset besar juga mengeluarkan agency cost dan pemeliharaan asset yang besar pula, karena kompleksitas dan besarnya lingkup operasional perusahaan. Deni, Khomsiyah, \& Rahayu (2004) menyatakan bahwa perusahaan besar pada dasarnya memiliki kekuatan financial yang lebih besar dalam menunjang kinerja, tetapi di sisi lain, perusahaan besar juga dihadapkan pada masalah keagenan yang lebih besar (karena lebih sulit untuk dimonitor) sehingga membutuhkan Good corporate governance yang lebih baik. Sementara perusahaan kecil bisa memiliki kesempatan bertumbuh yang tinggi, tetapi membutuhkan dana eksternal. Penelitian ini sejalan dengan Waswa, Mukras, \& David (2018), Alina \& Anis (2014), yang menyatakan ukuran perusahaan berpengaruh terhadap kinerja perusahaan. Akan tetapi penelitian ini tidak sejalan dengan Wehdawati, Fifi, \& Sufi (2015) menyatakan bahwa ukuran perusahaan tidak berpengaruh terhadap kinerja keuangan.

8. Pengaruh modal intelektuan terhadap kinerja keuangan (ROA).

Hasil penelitian menunjukan modal intelektual tidak berpengaruh terhadap kinerja keuangan. Dilihat dari $\mathrm{t}$ hitung sebesar $1,137<2,05183 \mathrm{t}$ tabel dengan nilai signifikansi sebesar 0,266 > 0,05 maka Ho diterima dan $\mathrm{H}_{3}$ ditolak. sehingga hipotesis 8 modal intelektual tidak berpengaruh terhadap kinerja keuangan.

Jumlah modal intelektual tidak berpengaruh terhadap kinerja keuangan. Modal intelektual adalah semua yang merupakan aset dan sumberdaya non tangible atau non physical dari sebuah organisasi mencakup proses, kapasitas inovasi, pola-pola, dan kolaborasi dari sumberdaya-sumberdaya aggota serta hubungan organisasi. Dalam modal ini jarang atau tidak pernah muncul dalam praktik akuntansi aset tidak berwujud meliputi proses, kapasitas inovasi, pola-pola, dan kolaborasi. Penelitian ini sejalan dengan Yuniasih, wirama, \& badera (2010), Widarjo (2011) yang menyatakan bahwa modal intelektual tidak berpengarh terhadap kinerja keuangan. Akan tetapi penelitian ini tidak sejalan dengan Wiwin, Nunung, \& Tevi (2015) yang menyatakan bahwa modal intelektual berpengaruh terhadap modal intelektual.

\section{SIMPULAN}

Tujuan penelitian ini untuk mengetahui Pengaruh Good Corporate Governance, Modal Intelektual, Ukuran Perusahaan Terhadap Kinerja Keuangan Pada Perusahaan Makanan. Dalam penelitian ini Good Corporate Governance terdiri dari Ukuran Dewan Direksi, Komisaris Indepen, Komite audit Indepen, Kepemilikan instituti, Kepemilikan manajerial dan Ukuran Dewan Komisaris. Dalam penelitian ini populasi berupa perusahaan makanan minuman yang terdaftar di BEI pada tahun 2017-2019. Sampel ditentukan menggunakan metode purposive sampling dan menghasilkan sebanyak 16 perusahan dan 36 data. Hasil penelitian menunjukan bahwa variabel komisaris independen, kepemilikan instituti, kepemilikan manajerial, dan modal intelektual tidak berpengaruh terhadap kinerja keuangan. 
Arief Abdul Aziz, Yuli Chomsatu Samrotun dan Riana Rachmawati Dewi, Pengaruh Good Corporate Governance, Modal Intelektual, Ukuran Perusahaan Terhadap Kinerja Keuangan Pada Perusahaan Makanan

Sedangkan variabel ukuran dewan direksi, komite audit independen, ukuran dewan komisaris, ukuran perusahaan berpengaruh terhadap kinerja keuangan.

\section{DAFTAR PUSTAKA}

A. A., \& A. C. (2014). Pengaruh Penerapan Corporate Governance Terhadap Kinerja Keuangan Perbankan (Studi Pada Perusahaan Perbankan Yang Terdaftar Di Bursa Efek Indonesia (BEI) Tahun 2010-2012). Diponegoro Journal Of Accounting, 3, 1-15.

Astuti, I. T. (2019). Pengaruh Good Corporate Governance Terhadap Kinerja Keuangan, Studi Empiris Perusahaan Makanan dan Minuman di Bursa Efek Indonesia tahun 2014-2017. Manajemen Fakultas Ekonomi Dan Bisnis.

Beasly. (1996). An Empirical Analysis of the Relation Between the Board of Director Composition and Financial Statement Fraud. Accounting Review (71), 443-465.

Candradewi, \& Sedana. (2016). Pengaruh Kepemilikan Manajerial, Intitusional dan Dewan Komisaris Independen Terhadap Return On Asset. EJurnal Manajemen Unud, 3163-3190.

D. D., Khomsiyah, \& Rahayu, R. G. (2004). Hubungan Corporate dan Kinerja Perusahaan. Denpasar: Prosiding Simposium Nasioal Akuntansi 7.

Diyanty, M., \& Yusniar, M. W. (2019). Pengaruh mekanisme Good Corporate Governance terhadap Kinerja Keuangan pada perbankan yang terdaftar di Bursa Efek Indonesia (BEI). Jurnal Wawasan Manajemen, 49-65.

E. S., \& M. M. (2003). Analisis Struktur Kepemilikan, NilaiPerusahaan, Investasi dan Ukuran Dewan Direksi. Surabaya: Simposium NasionalAkuntansi.

Faisal. (2005). Struktur Kepemilikan Dan Mekanisme Corporate. Analisis Agency Cost, 197-207.

Ghozali (Director). (2011). Aplikasi Analisis Multivariate dengan Program IBM SPSS 19-5/E [Motion Picture].

H. P., \& F. A. (2020). Pengaruh Mekanisme Corporate Governance, Rasio Kecukupan Modal, Dan Ldr Terhadap Kinerja Keuangan Perbankan. Menara Ilmu, 62-77.

Handayani. (2018). Pengaruh GCG Terhadap Kinerja Keuangan Perusahaan Pada Perusahaan Manufaktur di BEI.

O. S., \& I. S. (2020). Pengaruh Good Corporate Governance Terhadap Kinerja Keuangan Pada Sektor Barang Konsumsi Di BEI. Jurnal Ilmiah Akuntansi, 13-21.

S. S., \& S. M. (2017). Pengaruh GCG Terhadap Kinerja Keuangan dan Nilai Perusahaan (Studi pada Badan Usaha Milik Negara (BUMN) yang Terdaftar di Bursa Efek Indonesia Periode 2012-2015). Jurnal Administrasi.

T. S. (2002). Modal Intelektual Modal Intelektual Kekayaan Baru. Jakarta: PT Alex Media Komputindo.

Tandean, \& Winnie. (2016). The Effect of Good Corporate Governance on Tax Avoidance : An Empirical Study on Manufacturing Companies Listed in IDX Period 2010-2013 . Asian Jourrnal of Accounting research, 28-38.

W. S., N. N., \& T. L. (2015). Pengaruh Modal Intelektual, Kinerja Keuangan, Investasi pada Riset dan Pengembangan terhadap Nilai Perusahaan (Pada Perusahaan Manufaktur yang terdaftar di BEI) . Jurnal Aset (Akuntansi Riset), $29-42$.

Waswa, C. W., Mukras, M. S., \& D. O. (2018). Pengaruh Likuiditas terhadap Kinerja Keuangan Industri Gula di Kenya. Jurnal Internasional Pendidikan dan Penelitian, 29-44.

Wehdawati, F. S., \& S. J. (2015). Pengaruh Mekanisme Good Corporate Governance Dan Struktur Kepemilikan Terhadap Kinerja Keuangan Perusahaan Manufaktur Yang Terdaftar Di BEI Tahun 2010-2012. Jurnal Wawasan Manajemen, 206-216.

Widarjo. (2011). Pengaruh Modal Intelektual Dan pengungkapan Modal Intelektual Pada Nilai Perusahaan. Aceh: Sinopsium Nasional Akuntansi XIV Aceh.

Widyati, M. F. (2013). Pengaruh dewan direksi, komisaris independen, komite audit, Kepemilikan manajerial dan kepemilikan institusional Terhadap kinerja keuangan. Jurnal Ilmu Manajemen.

Yuniasih, wirama, \& badera. (2010). Eksplorasi Kinerja Pasar. 